\title{
Effect of Interventions for Non-Medical Emergency Transportation: A Systematic Review
}

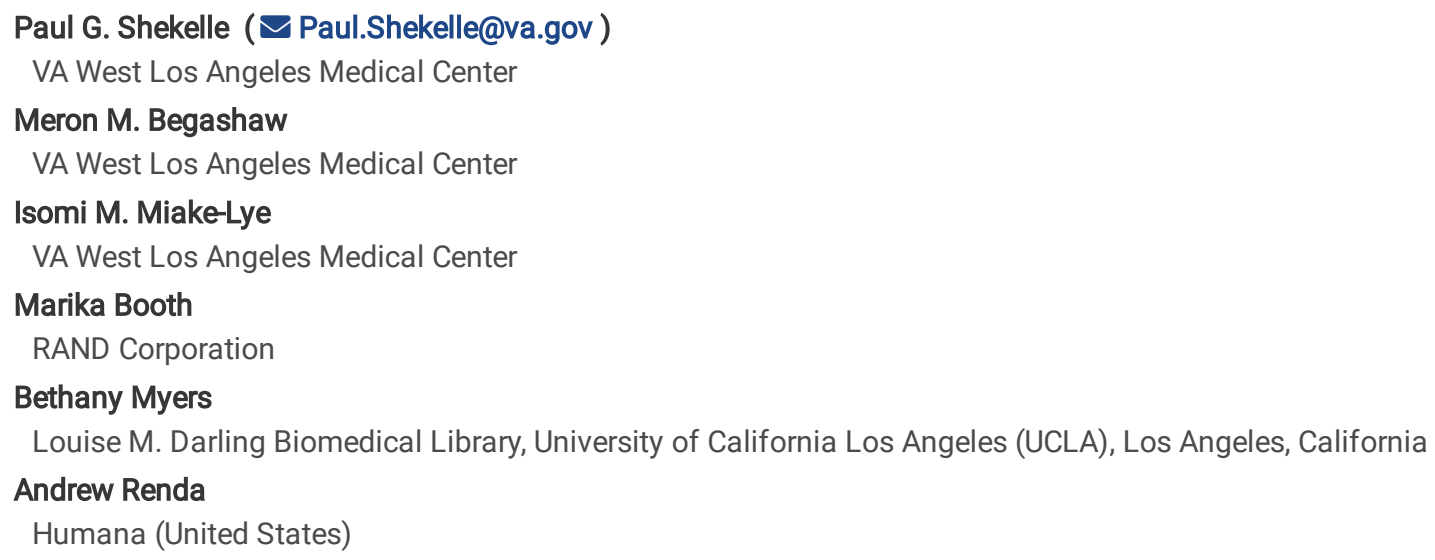

Keywords: non-emergency medical transportation, health outcomes, systematic review

Posted Date: October 29th, 2021

DOI: https://doi.org/10.21203/rs.3.rs-1002067/v1

License: (c) (i) This work is licensed under a Creative Commons Attribution 4.0 International License. Read Full License 


\section{Abstract}

Introduction: Transportation is an important social determinant of health. We conducted a systematic review of the associations on health and health care utilization of interventions aimed at reducing barriers to non-emergency transportation and non-medical transportation.

Methods: We searched multiple databases and the gray literature through late January 2021. Included studies needed to assess an intervention targeted at non-emergency or non-medical transportation barriers, report missed (or kept) visits, health care utilization, costs, or health outcomes. Data extraction was performed in duplicate and included information about study design, results, and risk of bias. Primary outcomes were frequency of missed appointments, health care utilization, costs, and health outcomes. Synthesis was both narrative and meta-analytic using a random effects model.

Results: 12 studies met inclusion criteria, 3 randomized trials, 1 controlled trial, and 8 observational studies. All included studies had some element of risk of bias. Populations studied usually had chronic or serious health conditions or were poor. Interventions included van rides, bus or taxi vouchers, ride-sharing services, and others. Meta-analysis of 7 studies ( 3 trials, 4 observational studies) yielded a pooled estimate of missed appointments $=0.63(95 \%$ confidence interval $[\mathrm{Cl}] 0.48,0.83)$ favoring interventions. Evidence on cost, utilization, and health outcomes were too sparse to support conclusions. Evidence on the effect of non-medical transportation is limited to a single study.

Conclusions and Relevance: Interventions aimed at non-emergency transportation barriers to access health care are associated with fewer missed appointments; the association with costs, utilization or health outcomes is insufficiently studied to reach conclusions.

This review was registered in PROSPERO as ID CRD42020201875

\section{Introduction}

Social determinants of health are receiving increasing attention as a target for interventions to try and improve health outcomes. Transportation barriers are one category of social determinants. Transportation barriers can be categorized as Emergency Medical Transport (EMT), NonEmergent Medical Transport (NEMT), and Non-Medical Transport (NMT). Transport for medical emergencies typically happens through the 911 system and occurs in ambulances with trained personnel. Non-emergency transport can be provided by people without medical training and occur in vans or cars. Barriers to NEMT and NMT can be assessed with validated screening instruments (such as the Accountable Health Communities Health-Related Social Needs Screening Tool question "In the past 12 months, has lack of reliable transportation kept you from medical appointments, meetings, work or from getting things needed for daily living?") (1) NEMT barriers have been estimated to cause foregone or delayed care in up to 3.6 million people annually and be responsible for $25 \%$ or more of missed clinic appointments.(2, 3) More than $20 \%$ of older adults, and even more with chronic diseases, do not drive. This means these persons also have barriers to non-medical transport such as shopping and social engagements, which may also be deleterious to health. Medicaid and Medicare Advantage plans show increasingly widespread use of non-emergency medical transportation (NEMT), via Medicaid home and community-based services (HCBS) and Medicare Advantage supplemental benefits.(4) Solutions include company-contracted transportation services, as well as vouchers for other public transportation options. The arrival of rideshare programs (such as Uber and Lyft) have been embraced as a new option to overcome transportation barriers.(5) The current COVID pandemic further exacerbates NEMT and NMT challenges, as public transportation options have stopped or operated at reduced schedules. A prior review, whose search was performed in January 2018 , identified 10 studies meeting inclusion criteria, which were broad and included multicomponent interventions where the transportation component may have been small and/or unstated in size.(6) Since 2018 new studies have been published, which focused primarily on transportation barriers. In order to better understand NEMT and NMT interventions studies and their effects, we conducted a systematic review of published and gray literature studies of interventions for transportation, both non-emergency medical and non-medical, on utilization, costs, and health outcomes in children and adults.

\section{Methods}

This topic was developed in consultation with the sponsor, Humana. This review was registered in PROSPERO as ID CRD42020201875.

\section{Data Sources and Searches}

The search strategy, including the search terms and databases used, was created by an experienced reference librarian. We conducted searches in PubMed and Cochrane Reviews from inception to 01/26/2021. The searches used included "health services accessibility," "appointments and schedules," "transportation of patients," and "rideshare" as the set of terms. See Appendix A for complete search strategy. In addition, we searched the Social Interventions Research \& Evaluation Network (SIREN) database on 01/26/21 using their Social Determinant of Health 'Transportation' filter categorization. SIREN is a University of California, San Francisco project focused on catalyzing high quality research, collecting, summarizing, and disseminating research, and increasing capacity to evaluate social determinants of health interventions. (7) Lastly, we searched for gray literature by performing a Google search on 2/4/2021 using the term "non-emergency medical transportation evaluations" and evaluating the first 5 pages retrieved (58 hits). 
Two team members (PGS and IML) working independently screened the titles of retrieved citations. For titles deemed relevant by at least 1 person, abstracts were then screened independently in duplicate by team members. All disagreements were reconciled through group discussion. Full-text review was conducted in duplicate by 2 independent team members (PGS and IML), with any disagreements resolved through discussion. In order to be included, a study had to be an evaluation of an intervention whose focus was on non-emergency transportation access to health resources or non-medical transportation that reported health care outcomes such as missed appointments, costs, and clinical processes and outcomes. As our focus was interventions applicable to the United States, we excluded publications that were describing studies conducted in low- and middleincome countries. Studies whose interventions were multicomponent where the contribution of transportation assistance was small or unstated, such as studies of patient navigators, were excluded. $(8,9)$ We also excluded studies that were focused on the exercise outcomes of engaging with certain modes of transportation (e.g., cardiovascular health outcomes from increased cycling or walking), and those without health care utilization or outcomes.

\section{Data Extraction and Quality Assessment}

Data extraction was completed in duplicate (by PGS/MMB). All discrepancies were resolved with full group discussion. We abstracted data on the following: study design, sample size, enrolled population, intervention, and outcomes measured. To assess risk of bias we used the Cochrane Risk of Bias Tool,(10) the Risk of Bias in Non-randomized Studies of Interventions tool (ROBINS-I),(11) or an adaptation of the National Institutes of Health's Quality Assessment Tool for Before-After (Pre-Post) Studies with No Control instrument.(12)

\section{Data Synthesis and Grading}

We grouped the interventions into 2 broad categories: those that were just for non-emergency medical transportation (in all cases transportation to clinic/healthcare visits) and interventions that included transportation for non-medical reasons (shopping, etc.) We grouped outcomes into 4 broad categories: (1) missed clinic visits, (2) healthcare resource utilization, (3) medical costs, and (4) health outcomes.

\section{Statistical Analysis}

Odds-ratios (OR) were estimated for each study, comparing pre- to post- intervention for observational studies and intervention to control groups for the randomized control trials. Random effects meta-analysis was performed for outcomes with at least 3 studies. To account for differences in study design types, stratified pooled results are presented along with overall pooled results. Tests of heterogeneity were performed using the $\mathrm{I}^{2}$ statistic. Values of the $\mathrm{I}^{2}$ statistic closer to $100 \%$ represent high degrees of heterogeneity. The Begg rank correlation(13) and Egger regression asymmetry tests were used to examine publication bias. All analyses were conducted in R.4.0.2.

\section{Rating the Certainty of Evidence}

We based our ratings on the certainty of evidence on the factors considered in the Grading of Recommendations Assessment, Development and Evaluation (GRADE) system,(14) and then supplemented by other factors (including mechanistic and parallel evidence) as proposed by Howick and colleagues (15) and as used by the National Academy of Medicine. (16)

Role of the Funding Source

Funding was provided by Humana. The funder helped set the scope of the review and participated as an author in putting the results in context.

\section{Results}

\section{Description of the Evidence}

We identified 3463 potentially relevant citations. Fifty-three publications underwent full-text review, of which 41 publications were excluded (see Appendix B). A total of 12 publications were identified as meeting inclusion criteria (see Figure 1). Of these 12 studies, 3 were Randomized Controlled Trials (RCTs), 1 was a controlled clinical trial, and 8 were observational studies. One study was conducted in England, the rest were conducted in the United States. Details of included studies are presented in the Evidence Table (see Table 1).

All controlled trials were judged as having at least 1 domain as being at high risk of bias, but this was because it is not possible to blind participants and personnel to the intervention (see Appendix Table 1). Two of the four trials were judged as being at low risk of bias for all other domains. $(17,18)$ Two of the three controlled observational studies were judged as being at low risk of bias in all domains. $(19,20)$ See Appendix Table 2. All pre-post studies were limited by one or more of small sample size or loss to follow-up (see Appendix Table 3)

\section{Associations with missed clinic visits and Emergency Department visits}


Nine studies reported on made or missed clinic visits. $(17,19,21-27)$ Three of these studies were controlled trials, $(17,18,23) 1$ was a controlled before-and-after study,(19) and the rest were pre/post studies.(21, 22, 25-27) The enrolled populations were a heterogenous mix of patients with specific conditions (Human Immunodeficiency Virus [HIV], or in need of cervical cytology follow-up, or prenatal care) or patients who were poor, or both. Six studies used as their transportation intervention taxicab or rideshare services (Lyft or Uber), $(18,19,23,25-27) 2$ used van rides or bus tickets, $(17,21)$ and in one study the intervention was advice and assistance with transportation.(22) One study reported its outcomes as means. (21) Seven studies measured utilization in terms of the proportion of clinic appointments, either missed or kept. The random effects pooled estimate of these 7 studies on missed appointments was an odds ratio of $0.63(95 \% \mathrm{Cl}[0.48,0.83])$ in favor of the intervention (see Figure 2$)$. The $\mathrm{I}^{2}$ statistic was $76 \%$. Pooled results from only the 3 controlled trials (OR=0.71, $95 \% \mathrm{Cl}[0.44,1.14]$ were not statistically different from pooled results of the remaining 4 observational studies (OR=0.58, $95 \% \mathrm{Cl}[0.41,0.82]$. There was no statistical evidence of publication bias (Eggar's test $p=0.24$, Begg's test $p=0.38$ ). The two studies that could not be included in the pooled analysis showed no statistically significant difference in 1 ) the self-report of the number of HIV visits before and during an intervention that consisted of giving free medical van transportation to and from the clinic for HIV positive women who had been poorly compliant to keeping medical appointments, although the self-reported missed clinic appointments did decline (21); and 2) the number of patients making same-day cancellations for Magnetic Resonance Imaging (MRI) appointments; in this study only $2 \%$ of patients used an offer of a ride-sharing service, making any difference in cancellations due to the intervention very hard to detect.

Two additional studies reported utilization in terms of Emergency Department (ED) visits. The first was a controlled clinical trial that offered 394 Medicaid beneficiaries free rideshare services to come for scheduled clinic visits and compared this to 392 other clinic patients as control.(23) Almost all participants were Black females, the mean age was 46 years. The study found no differences in ED visits at 7 or 30 days; however only $20 \%$ of eligible patients in the intervention group actually used the rideshare service. The second study assessed the effect of the use of transportation brokerage services for non-emergency medical transportation in adult Medicaid beneficiaries with diabetes, and found that the use of brokerage services did not significantly reduce the probability of ED visits for diabetes.(20)

\section{Associations with healthcare resource utilization and costs}

Six studies reported costs outcomes, one was an RCT,(28) one was a controlled before-and-after study,(20) three were pre/post studies,(20,26, 27) and one was the controlled clinical trial of rideshare services for Medicaid patients mentioned in the prior section.(23) In the latter study, the mean cost of the rideshare per patient who consented was $\$ 14.00$; in one pre/post study of a ride share for patients scheduled for MRI visits the mean cost was $\$ 17.92,(26)$ and in another pre-post study the mean cost for sickle cell patients was $\$ 67 .(27)$ In a study of 4 general practices in England,(28) intervention practices were given an additional 1500 pounds sterling plus technical assistance to improve over the next 6 months their system for making appointments and helping patients with transportation barriers, which included links to community transport, making appointment times convenient for existing bus schedules, providing charging stations for electric scooters, and at one clinic creating an appointment slot for patients requiring taxi services. Two of the three intervention clinics spent $£ 2262$ and $£ 930$ of additional money on developing their intervention. Staff time devoted to the intervention was estimated at between $£ 112$ and $£ 2651$. In a database analysis of the effect of transportation brokerage services on Medicaid expenditures in Georgia and Kentucky, the use of the brokerage service was estimated at decreasing the monthly per person expenditure (inpatient plus outpatient) by about $\$ 18$ for adults with diabetes and for children with asthma, despite increases in use of health services and prescription drugs (for diabetic patients).(20) All of these interventions were for non-emergency medical transportation to clinic. In one study that included non-medical transportation, discussed below, the cost was $\$ 500$ per month per patient. (24) One additional evaluation of the use of a ride-sharing program was reported in a blog but could not be included as evidence because it did not report information on the sample sizes, which precluded statistical testing of differences between groups.(29)

\section{Associations with health outcomes}

Two studies assessed health outcomes. One of these studies was the assessment of transportation brokerage services, discussed above.(20) In this study, the use of brokerage services for adult patients with diabetes decreased the probability of having an ambulatory care sensitive condition admission by a statistically significant 0.1 percent a month, whereas for children with asthma there were no such benefits seen. In the only study that assessed an intervention that included non-medical transportation, 150 patients of an urban academic medical center who were over the age of 60 (mean age $=72$ ), had a chronic disease, and reported transportation barriers were offered unlimited ridesharing for 3 months. (24) The mean number of rides during this time period was 69 , and the mean cost per subject was $\$ 500$ per month. Patients also received a device to measure step counts, these did not significantly change from before the intervention to during the intervention. A post-intervention-only assessment of health status, limited by a $31 \%$ non-response rate, was reported as showing $92 \%$ of subjects having improved quality-of-daily life, but no data are provided in the publication. Also, the published paper reports no significant differences in pre- and post-intervention measures of the Satisfaction with Life survey and the Geriatric Depression Scale; however again no data are reported.

\section{Certainty of Evidence}

We judged the certainty of evidence that providing free Non-Emergency Medical Transportation is associated with a decrease in missed clinic appointments is High, based on the reasonably consistent results seen in controlled trials and observational studies and the strong mechanism 
that the intervention of providing free transportation might mitigate transportation barriers to care. We judged all other outcomes as being Low or Very Low certainty evidence, due to limitations in study design, and/or execution (see Table 2).

\section{Discussion}

A principal conclusion of this review is that providing transportation means to patients with transportation barriers is associated with a significant reduction in the number of missed clinic appointments. With two exceptions, one a controlled trial where only $20 \%$ of eligible patients actually used the ride sharing service (23) and the other a pre-post study where only $2 \%$ of patients used the ride sharing service,(26) moderately fewer missed clinic appointments was a consistent finding across studies of different design (observational, RCT), different study populations (pregnant women, patient receiving cancer care, poor adults, etc.) and different kinds of transportation options (taxicab vouchers, free bus tickets, free ride-share, etc.).

A second conclusion is that assessments of health outcomes, utilization (other than clinic visits) and costs have been rarely studied. Even in studies that included cost data, this was mostly about the cost of giving the intervention and not about effects on total health care costs. Only one study assessed the effect on health care costs, and this study was not about providing transportation per se, but rather the use of transportation brokers to try and reduce the costs of non-emergency medical transportation. Those results are consistent with a modeling study, not included as empirical evidence, which estimated that with use of "modern" (ride-sharing services) non-emergency medical transportation there may be a savings of $\$ 268$ per user compared with traditional means of non-emergency medical transportation.(30)

A third conclusion is that the effect of providing non-medical transportation - such as to-and from-the grocery store, or shopping for other items needed for daily living, or social engagements - has essentially been unstudied. The one study that evaluated transportation including nonmedical needs was limited by methods issues (such as a high loss to follow-up) and a lack of reporting.

These findings have important implications as policymakers, payers, and clinicians search for opportunities to address the health-related social needs of patients and populations. First, reducing missed appointments is assumed to be an important intermediate step towards improved health outcomes. Facilitating access to preventive and primary care services may improve health screening rates, early diagnosis of health conditions, and clinical quality measures. Some data suggest that both the frequency and regularity of primary care provider encounters is associated with better medication adherence and glucose control in patients with diabetes.(31) Thus, under this assumption current evidence justifies expansion of NEMT offerings. NEMT is a required benefit in the Medicaid program to ensure that certain Medicaid beneficiaries have access to transportation to and from medical care. States have flexibility in designing and implementing their NEMT benefits, however there are opportunities to test and standardize the optimal approach. Medicare Advantage plans may offer NEMT to beneficiaries via supplemental benefits. Inherent in these opportunities is the obligation to test, learn and establish the effects on health outcomes. Such work can help establish the optimal model(s) and their effects on health, healthcare resources utilization and overall cost of care.

Increasing access to non-medical transportation may improve health outcomes in a variety of ways, including providing access to grocery stores with more nutritious food and increasing social contacts. Increased access to NMT is listed as an option in a recent Centers for Medicare \& Medicaid Services letter to state officials, which says: "States have the option to cover non-medical transportation to enable individuals receiving Medicaid-funded HCBS to gain access to such activities and resources when other options, such as transportation by family, neighbors, friends, or community agencies, are unavailable. Examples include transportation to grocery stores and places of employment."

(https://www.medicaid.gov/federal-policy-guidance/downloads/sho21001.pdf ). Medicare Advantage plans may utilize newer pilot opportunities from Center for Medicare \& Medicaid Innovation (CMMI), including Special Supplemental Benefits for the Chronically III (SSBCI) and Value-Based Insurance Design (VBID). Increased access to NMT should be tested rigorously.

\section{Limitations}

There are several limitations to this review. The main limitation of this review is the quantity and quality of the existing evidence. The majority of studies available were observational, which limits our ability to draw strong conclusions about the effect of the interventions. Nevertheless, the few controlled trials that were identified had results consistent with the observational studies. Secondly, we pooled studies across study designs, but results of pooling studies within study design were consistent and there was no evidence that the controlled trials reported smaller or different results than the observational studies. Thirdly, despite the lack of statistical evidence of publication bias there may be more evaluations of interventions addressing transportation barriers than are reported. The effect of adding in these un-reported studies to those that are published is unknown.

\section{Conclusions}

In conclusion, the evidence for providing NEMT to patients with transportation barriers shows a clear association with fewer missed clinic visits. Studies of the association of NEMT on health outcomes and costs are thus far too few to draw conclusions. We assume that kept clinic visits should result in better health outcomes, but proving under what circumstances this is correct, and any effect on health care costs, should be a 
primary focus of future research. NMT is essentially un-studied to date. Studies of the effect on health and financial outcomes of transportation services will help create scalability and sustainability of these services.

\section{Abbreviations}

Cl: Confidence Interval

CMMI: Center for Medicare \& Medicaid Innovation

ED: Emergency Department

EMT: Emergency Medical Transport

GRADE: Grading of Recommendations Assessment, Development and Evaluation

HCBS: Home and Community-Based Services

HIV: Human Immunodeficiency Virus

MRI: Magnetic Resonance Imaging

NEMT: Non-Emergent Medical Transport

NMT: Non-Medical Transport

OR: Odds Ration

RCT: Randomized Controlled Trial

ROBINS-I: Risk of Bias in Non-randomized Studies of Interventions

SIREN: Social Interventions Research \& Evaluation Network

SSBCl: Special Supplemental Benefits for the Chronically III

VBID: Value-Based Insurance Design

\section{Declarations}

Ethics approval and consent to participate

Not applicable.

Consent for publication

Not applicable.

Availability of data and materials

All data used in these analyses are presented in the Evidence Table or Appendices.

Competing interests

Not applicable.

Funding

Authors Shekelle, Begashaw, Miake-Lye, and Booth received grant support to conduct this research from Humana to their respective institutions (UCLA, RAND). Author Renda is an employee of Humana.

Authors' contributions

PGS contributed to the conceptualization, methodology, formal analysis, writing-original draft, writing-review and editing of the manuscript. MMB contributed to the investigation, visualization, project administration, writing-review, and editing of the manuscript. IML contributed to the conceptualization, methodology, writing-review, and editing of the manuscript. MB contributed to software, visualization, and formal analysis of 
the manuscript. BM contributed to methodology and resources for the manuscript. AR contributed to the conceptualization, methodology, writingreview, and editing of the manuscript.

\section{Acknowledgements}

Not applicable.

\section{References}

1. Center for Medicare and Medicaid Innovation. The Accountable Health Communities Health-Related Social Needs Screening Tool.

2. Syed ST, Gerber BS, Sharp LK. Traveling towards disease: transportation barriers to health care access. J Community Health. 2013;38(5):97693.

3. National Academies of Sciences E, and Medicine. Cost-Benefit Analysis of Providing Non-Emergency Medical Transportation. Washington, DC: The National Academies Press.; 2005.

4. Crook H, Zheng J, Bleser W, Whitaker R, Masand J, Saunders R. How Are Payment Reforms Addressing Social Determinants of Health? Policy Implications and Next Steps. Duke Margolis Center for Health Policy; 2021.

5. Powers BW, Rinefort S, Jain SH. Nonemergency Medical Transportation: Delivering Care in the Era of Lyft and Uber. Jama. 2016;316(9):921-2.

6. Starbird LE, DiMaina C, Sun CA, Han HR. A Systematic Review of Interventions to Minimize Transportation Barriers Among People with Chronic Diseases. J Community Health. 2019;44(2):400-11.

7. UCSF. Social Interventions Research \& Evaluation Network. https://sirenetworkucsfedu/tools/evidence-library. Accessed 19 February 2021.

8. Esperat MC, Flores D, McMurry L, Feng D, Song H, Billings L, et al. Transformacion Para Salud: a patient navigation model for chronic disease self-management. Online J Issues Nurs. 2012;17(2):2.

9. Percac-Lima S, Grant RW, Green AR, Ashburner JM, Gamba G, Oo S, et al. A culturally tailored navigator program for colorectal cancer screening in a community health center: a randomized, controlled trial. J Gen Intern Med. 2009;24(2):211-7.

10. Cochrane Methods Bias. RoB 2: A revised Cochrane risk-of-bias tool for randomized trials. https://methods.cochrane.org/bias/resources/rob2-revised-cochrane-risk-bias-tool-randomized-trials. Accessed 19 February 2021.

11. Sterne JA, Hernan MA, Reeves BC, Savovic J, Berkman ND, Viswanathan M, et al. ROBINS-I: a tool for assessing risk of bias in nonrandomised studies of interventions. BMJ. 2016;355:i4919.

12. Study Quality Assessment Tools: National Heart, Lung, and Blood Institute. https://www.nhlbi.nih.gov/health-topics/study-qualityassessment-tools. Accessed 19 February 2021.

13. Begg CB, Mazumdar M. Operating characteristics of a rank correlation test for publication bias. Biometrics. 1994;50(4):1088-101.

14. The GRADE Working Group. www.gradeworkinggroup.orgwww. Accessed 19 February 2021.

15. Howick J, Glasziou P, Aronson JK. The evolution of evidence hierarchies: what can Bradford Hill's 'guidelines for causation' contribute? J R Soc Med. 2009;102(5):186-94.

16. The National Academies of Sciences, Engineering, and Medicine. Evidence-Based Practice for Public Health Emergency Preparedness and Response. Washington, DC; 2020.

17. Marcus AC, Crane LA, Kaplan CP, Reading AE, Savage E, Gunning J, et al. Improving adherence to screening follow-up among women with abnormal Pap smears: results from a large clinic-based trial of three intervention strategies. Med Care. 1992;30(3):216-30.

18. Melnikow J, Paliescheskey M, Stewart GK. Effect of a transportation incentive on compliance with the first prenatal appointment: a randomized trial. Obstet Gynecol. 1997;89(6):1023-7.

19. Chaiyachati KH, Hubbard RA, Yeager A, Mugo B, Shea JA, Rosin R, et al. Rideshare-Based Medical Transportation for Medicaid Patients and Primary Care Show Rates: A Difference-in-Difference Analysis of a Pilot Program. J Gen Intern Med. 2018;33(6):863-8.

20. Kim J, Norton EC, Stearns SC. Transportation brokerage services and Medicaid beneficiaries' access to care. Health Serv Res. 2009;44(1):14561.

21. Andersen M, Hockman E, Smereck G, Tinsley J, Milfort D, Wilcox R, et al. Retaining women in HIV medical care. J Assoc Nurses AIDS Care. 2007;18(3):33-41.

22. Bryan J, Greger H, Miller M, Weinberger M, Loehrer P. An Evaluation of the Transportation Needs of Disadvantaged Cancer Patients. Journal of Psychosocial Oncology. 1991;9(3):23-35.

23. Chaiyachati KH, Hubbard RA, Yeager A, Mugo B, Lopez S, Asch E, et al. Association of Rideshare-Based Transportation Services and Missed Primary Care Appointments: A Clinical Trial. JAMA Intern Med. 2018;178(3):383-9.

24. Saxon L, Ebert R, Sobhani M. Health impacts of unlimited access to networked transportation in older adults. Journal of mHealth. 2019. 
25. Vais S, Siu J, Maru S, Abbott J, St Hill I, Achilike C, et al. Rides for Refugees: A Transportation Assistance Pilot for Women's Health. J Immigr Minor Health. 2020;22(1):74-81.

26. Whorms DS, Narayan AK, Pourvaziri A, Miles RC, Glover Mt, Herrington J, et al. Analysis of the Effects of a Patient-Centered Rideshare Program on Missed Appointments and Timeliness for MRI Appointments at an Academic Medical Center. J Am Coll Radiol. 2020.

27. S. Vais LT, A. Williams, A. Sobota. Rethinking rideshares: A transportation assistance pilot for pediatric patients with Sickle Cell Disease. J Health Care Poor Underserved. 2020;31(3):1457-70.

28. Ford JA, Jones AP, Wong G, Barton G, Clark A, Sims E, et al. Improving primary care Access in Context and Theory (I-ACT trial): a theoryinformed randomised cluster feasibility trial using a realist perspective. Trials. 2019;20(1):193.

29. Powers B, Rinefort S, Jain S. Health Affairs Blog. https://www.healthaffairs.org/do/10.1377/hblog20180907.685440/full/. Accessed 19 February 2021.

30. Rochlin DH, Lee CM, Scheuter C, Milstein A, Kaplan RM. Economic Benefit of "Modern" Nonemergency Medical Transportation That Utilizes Digital Transportation Networks. Am J Public Health. 2019;109(3):472-4.

31. Dobbins JM, Elliott SW, Cordier T, Haugh G, Renda A, Happe L, et al. Primary Care Provider Encounter Cadence and HbA1c Control in Older Patients With Diabetes. Am J Prev Med. 2019;57(4):e95-e101.

\section{Tables}

Table 1. Evidence Table 


\begin{tabular}{|c|c|c|c|c|c|c|c|}
\hline $\begin{array}{l}\text { Author, } \\
\text { Date, ID }\end{array}$ & Study Design & Sample Size & $\begin{array}{l}\text { Enrolled } \\
\text { Population }\end{array}$ & Intervention & $\begin{array}{l}\text { Includes non- } \\
\text { medical } \\
\text { transportation? }\end{array}$ & $\begin{array}{l}\text { Outcomes } \\
\text { Measured }\end{array}$ & Results \\
\hline $\begin{array}{l}\text { Andersen, } \\
2007 \text { (21) }\end{array}$ & $\begin{array}{l}\text { Observational, } \\
\text { pre-post }\end{array}$ & $\begin{array}{l}\text { Pre }=61 \\
\text { Post }=61\end{array}$ & $\begin{array}{l}\text { Urban HIV } \\
\text { positive } \\
\text { women } \\
82 \% \text { on } \\
\text { Medicaid } \\
\text { 91\% African } \\
\text { American }\end{array}$ & $\begin{array}{l}1-800 \text { phone } \\
\text { number to call } \\
\text { for free, van } \\
\text { ride to doctor's } \\
\text { office }\end{array}$ & No & $\begin{array}{l}\text { Utilization } \\
\text { (self-report } \\
\text { number of } \\
\text { visits, self- } \\
\text { report number } \\
\text { of missed } \\
\text { opportunities) }\end{array}$ & $\begin{array}{l}\text { No change in self- } \\
\text { reported overall } \\
\text { HIV clinic visits, } \\
\text { but decreased } \\
\text { self-report of } \\
\text { missed } \\
\text { appointments } \\
\text { from } 6 \text { months } \\
\text { prior to the } \\
\text { intervention(mean } \\
1.92 \text { vs } 0.72 \text { ) }\end{array}$ \\
\hline $\begin{array}{l}\text { Bryan, } 1991 \\
(22)\end{array}$ & $\begin{array}{l}\text { Observational, } \\
\text { pre-post with } \\
\text { control }\end{array}$ & $\begin{array}{l}\text { Intervention = } \\
53 \\
\text { Control = } 52\end{array}$ & $\begin{array}{l}\text { Patients who } \\
\text { received } \\
\text { cancer care } \\
\text { and primary } \\
\text { care at } \\
\text { Wishard } \\
\text { Hospital } \\
\text { Mean age = } \\
63 \\
7 \% \text { African } \\
\text { American }\end{array}$ & $\begin{array}{l}\text { Both groups } \\
\text { received a } \\
\text { mailing } \\
\text { describing } \\
\text { resources to } \\
\text { assist with } \\
\text { transportation. } \\
\text { The } \\
\text { intervention } \\
\text { group got in } \\
\text { addition a } \\
\text { telephone } \\
\text { consultation } \\
\text { to address } \\
\text { possible } \\
\text { solutions to } \\
\text { transportation } \\
\text { problems. }\end{array}$ & No & $\begin{array}{l}\text { Utilization } \\
\text { (missed } \\
\text { appointments } \\
\text { as measured } \\
\text { by electronic } \\
\text { health record) }\end{array}$ & $\begin{array}{l}\text { Missed clinic } \\
\text { appointments } \\
\text { Intervention pre = } \\
23.7 \% \text {; post = } \\
23.6 \% \text {; Control pre } \\
=25.5 \% \text {, post = } \\
39.9 \%\end{array}$ \\
\hline $\begin{array}{l}\text { Chaiyachati, } \\
2018 \text { (23) }\end{array}$ & $\begin{array}{l}\text { Controlled } \\
\text { clinical trial }\end{array}$ & $\begin{array}{l}786 \text { (In } 2 \\
\text { practices) } \\
\text { Intervention = } \\
394 \\
\text { Control = } 392\end{array}$ & $\begin{array}{l}\text { Medicaid } \\
\text { adults } \\
\text { Mean age = } \\
46 \\
\\
95 \% \text { African } \\
\text { American }\end{array}$ & $\begin{array}{l}\text { Offered } \\
\text { rideshare for } \\
\text { free transport } \\
\text { to clinic }\end{array}$ & No & $\begin{array}{l}\text { Utilization } \\
\text { (appointments } \\
\text { kept as } \\
\text { measured by } \\
\text { electronic } \\
\text { health record) } \\
\\
7 \text { day or 30- } \\
\text { day } \\
\text { Emergency } \\
\text { Department } \\
\text { visits } \\
\text { Costs }\end{array}$ & $\begin{array}{l}\text { Missed } \\
\text { appointments } \\
\text { intervention = } \\
36.5 \% \text {, control = } \\
36.5 \% ; 7 \text { day ED } \\
\text { visits intervention } \\
=2 \% \text {, control = } \\
1 \% \text {; mean cost = } \\
\$ 14\end{array}$ \\
\hline $\begin{array}{l}\text { Chaiyachati, } \\
2018 \text { (19) }\end{array}$ & $\begin{array}{l}\text { Observational } \\
\text { Controlled } \\
\text { before-and- } \\
\text { after }\end{array}$ & $\begin{array}{l}506 \text { (in 2 } \\
\text { practices) } \\
\\
\text { Intervention = } \\
194\end{array}$ & $\begin{array}{l}\text { Medicaid } \\
\text { adults } \\
\text { Mean age = } \\
47 \\
\\
97 \% \text { African } \\
\text { American }\end{array}$ & $\begin{array}{l}\text { Offered } \\
\text { rideshare for } \\
\text { free transport } \\
\text { to clinic }\end{array}$ & No & $\begin{array}{l}\text { Utilization } \\
\text { (appointments } \\
\text { kept as } \\
\text { measured by } \\
\text { electronic } \\
\text { health record) }\end{array}$ & $\begin{array}{l}\text { Appoints kept } \\
\text { intervention pre = } \\
54 \% \text {, post = 68\%; } \\
\text { control pre = } 60 \% \text {, } \\
\text { post }=51 \%\end{array}$ \\
\hline
\end{tabular}




\begin{tabular}{|c|c|c|c|c|c|c|c|}
\hline $\begin{array}{l}\text { Author, } \\
\text { Date, ID }\end{array}$ & Study Design & Sample Size & $\begin{array}{l}\text { Enrolled } \\
\text { Population }\end{array}$ & Intervention & $\begin{array}{l}\text { Includes non- } \\
\text { medical } \\
\text { transportation? }\end{array}$ & $\begin{array}{l}\text { Outcomes } \\
\text { Measured }\end{array}$ & Results \\
\hline $\begin{array}{l}\text { Ford, } 2019 \\
(28)\end{array}$ & RCT & $\begin{array}{l}34 \\
\text { Intervention = } \\
29 \\
\text { Control = } 5 \\
\text { Participants } \\
\text { in } 4 \text { primary } \\
\text { care practices }\end{array}$ & $\begin{array}{l}\text { Adults greater } \\
\text { or equal to } 64, \\
\text { not high } \\
\text { utilizers and } \\
\text { no car access } \\
\text { Mean age = } \\
80\end{array}$ & $\begin{array}{l}\$ 2000 \text { cash } \\
\text { given to clinic } \\
\text { to arrange } \\
\text { transportation }\end{array}$ & No & $\begin{array}{l}\text { Patient- } \\
\text { perceived } \\
\text { ease of } \\
\text { appointment, } \\
\text { cost }\end{array}$ & $\begin{array}{l}\text { Equivalent annual } \\
\text { cost per older, } \\
\text { socio- } \\
\text { disadvantaged } \\
\text { older patient } \\
\text { without access to } \\
\text { a car was lowest } \\
\text { in practice with } \\
\text { call-stacking } \\
\text { system aimed to } \\
\text { develop closer } \\
\text { links with a } \\
\text { community } \\
\text { transport provider }\end{array}$ \\
\hline $\begin{array}{l}\text { Kim, } 2009 \\
(20)\end{array}$ & $\begin{array}{l}\text { Observational } \\
\text { Controlled } \\
\text { before-and- } \\
\text { after }\end{array}$ & $>50,000$ & $\begin{array}{l}\text { Children with } \\
\text { asthma, } \\
\text { adults under } \\
65 \text { with DM } \\
\text { Medicaid } \\
\\
\text { No details of } \\
\text { population } \\
\text { reported }\end{array}$ & $\begin{array}{l}\text { Transportation } \\
\text { brokerage } \\
\text { services (profit } \\
\text { or non-profit } \\
\text { organizations } \\
\text { who manage } \\
\text { nonemergency } \\
\text { medical } \\
\text { transportation } \\
\text { on a capitated } \\
\text { basis) }\end{array}$ & No & $\begin{array}{l}\text { Health, cost, } \\
\text { use of } \\
\text { transportation } \\
\text { services }\end{array}$ & $\begin{array}{l}\text { Statistically } \\
\text { significant } \\
\text { decreases in } \\
\text { monthly NEMT } \\
\text { expenditures per } \\
\text { person, \$18 } \\
\text { decrease in mean } \\
\text { monthly } \\
\text { expenditure per } \\
\text { person for both } \\
\text { patient groups; } \\
\text { decrease in } \\
\text { ambulatory care } \\
\text { sensitive } \\
\text { conditions in } \\
\text { diabetics }\end{array}$ \\
\hline $\begin{array}{l}\text { Marcus, } \\
1992(17)\end{array}$ & RCT & 2044 & $\begin{array}{l}\text { Women with } \\
\text { abnormal } \\
\text { cervical } \\
\text { cytology } \\
79 \% \text { <age } 45 \\
28 \% \text { African } \\
\text { American } \\
41 \% \text { Hispanic }\end{array}$ & $\begin{array}{l}\text { Bus tickets } \\
\text { mailed to } \\
\text { women with } \\
\text { note that } \\
\text { follow-up was } \\
\text { needed for } \\
\text { cervical } \\
\text { cytology result }\end{array}$ & No & $\begin{array}{l}\text { Loss to } \\
\text { follow-up }\end{array}$ & $\begin{array}{l}\text { Transportation } \\
\text { incentives had } \\
\text { significant } \\
\text { positive impact } \\
\text { on return rates } \\
\text { (adjusted odds } \\
\text { ratio }=1.48,(95 \% \\
\text { Cl } 1.06,2.06) \text { ) }\end{array}$ \\
\hline $\begin{array}{l}\text { Melnikow, } \\
1997(18)\end{array}$ & $\mathrm{RCT}$ & $\begin{array}{l}\text { Enrolled = } \\
104 \text { (in } 5 \\
\text { clinics) } \\
\text { Follow-up = } \\
86 \\
\text { Taxi voucher } \\
=34 \\
\text { Blanket } \\
\text { coupon =35 } \\
\text { Control =35 }\end{array}$ & $\begin{array}{l}\text { Pregnant } \\
\text { women in } \\
\text { need of pre- } \\
\text { natal care } \\
\text { Mean age = } \\
25 \\
53 \% \text { white }\end{array}$ & $\begin{array}{l}\text { Taxicab } \\
\text { voucher for } \\
\text { travel to pre- } \\
\text { natal } \\
\text { appointment }\end{array}$ & No & $\begin{array}{l}\text { Utilization } \\
\text { (appointment } \\
\text { kept) }\end{array}$ & $\begin{array}{l}\text { Unadjusted odds } \\
\text { ratio for keeping } \\
\text { first appointment } \\
=0.32(95 \% \mathrm{Cl} \\
0.12,0.88)\end{array}$ \\
\hline
\end{tabular}




\begin{tabular}{|c|c|c|c|c|c|c|c|}
\hline $\begin{array}{l}\text { Author, } \\
\text { Date, ID }\end{array}$ & Study Design & Sample Size & $\begin{array}{l}\text { Enrolled } \\
\text { Population }\end{array}$ & Intervention & $\begin{array}{l}\text { Includes non- } \\
\text { medical } \\
\text { transportation? }\end{array}$ & $\begin{array}{l}\text { Outcomes } \\
\text { Measured }\end{array}$ & Results \\
\hline $\begin{array}{l}\text { Saxon, } \\
2019(24)\end{array}$ & $\begin{array}{l}\text { Observational, } \\
\text { pre-post }\end{array}$ & $\begin{array}{l}\text { Pre }=150 \\
\text { Post }=103\end{array}$ & $\begin{array}{l}\text { Urban } \\
\text { academic } \\
\text { health center } \\
\text { patients; } 60 \\
\text { years of age } \\
\text { or older, } \\
\text { English- } \\
\text { speaking, had } \\
\text { a chronic } \\
\text { disease, had } \\
\text { self-reported } \\
\text { transportation } \\
\text { barriers }\end{array}$ & $\begin{array}{l}3 \text { months of } \\
\text { free unlimited } \\
\text { ride-share } \\
\text { transportation } \\
\text { (not just for } \\
\text { medical } \\
\text { needs) }\end{array}$ & Yes & $\begin{array}{l}\text { Health status } \\
\text { (HRQoL; daily } \\
\text { step count) }\end{array}$ & $\begin{array}{l}\text { No significant } \\
\text { differences } \\
\text { between pre-and } \\
\text { post-study daily } \\
\text { step counts or } \\
\text { validated } \\
\text { measures of } \\
\text { Satisfaction with } \\
\text { Life and Geriatric } \\
\text { Depression }\end{array}$ \\
\hline & & & $\begin{array}{l}\text { Mean age = } \\
72 \\
54 \% \text { white }\end{array}$ & & & & \\
\hline $\begin{array}{l}\text { Vais, } 2020 a \\
(25)\end{array}$ & $\begin{array}{l}\text { Observational, } \\
\text { pre-post }\end{array}$ & $\begin{array}{l}78 \\
\text { Ride utilizers } \\
=19 \\
\text { Denied } \\
\text { transportation } \\
\text { issues =30 } \\
\text { Rescheduled } \\
<72 \text { hours } \\
=12 \\
\text { Could not be } \\
\text { reached by } \\
\text { telephone }=17\end{array}$ & $\begin{array}{l}\text { Gynecology } \\
\text { patients who } \\
\text { reported } \\
\text { difficulties } \\
\text { with } \\
\text { transportation } \\
\text { (excluding } \\
\text { obstetrics) } \\
\text { Mean age = } \\
36-42 \\
100 \% \text { African } \\
\text { American }\end{array}$ & $\begin{array}{l}\text { Free roundtrip } \\
\text { transportation } \\
\text { to clinic visit } \\
\text { using ride- } \\
\text { share }\end{array}$ & No & $\begin{array}{l}\text { Utilization } \\
\text { (clinic no- } \\
\text { show rate), } \\
\text { costs }\end{array}$ & $\begin{array}{l}\text { Weekly no-show } \\
\text { rate pre=27.8\%, } \\
\text { post=19.4\%; } \\
\text { average cost of } \\
\text { rides was } \$ 32.48\end{array}$ \\
\hline $\begin{array}{l}\text { Vais, 2020b } \\
(27)\end{array}$ & $\begin{array}{l}\text { Observational } \\
\text { pre-post }\end{array}$ & $\begin{array}{l}86 \\
\text { Ride utilizers } \\
=32 \\
\text { Denied } \\
\text { transportation } \\
\text { issues = } 31 \\
\text { Could not be } \\
\text { reached = } 23\end{array}$ & $\begin{array}{l}\text { Patients with } \\
\text { sickle cell } \\
\text { disease and } \\
\text { their } \\
\text { caregivers } \\
\text { attending a } \\
\text { public urban } \\
\text { pediatric } \\
\text { specialty } \\
\text { clinic } \\
\text { Mean age = } \\
13 \\
73 \% \text { African } \\
\text { American }\end{array}$ & $\begin{array}{l}\text { Free roundtrip } \\
\text { transportation } \\
\text { to clinic visit } \\
\text { using ride- } \\
\text { share }\end{array}$ & No & $\begin{array}{l}\text { Utilization } \\
\text { (clinic no- } \\
\text { show rate), } \\
\text { costs }\end{array}$ & $\begin{array}{l}\text { Decrease in no- } \\
\text { show rate from } \\
20.4 \% \text { to } 11.9 \% \\
\text { using } \\
\text { transportation } \\
\text { service; total cost } \\
\text { of rideshares = } \\
\$ 2175 ; \text { average } \\
\text { round trip cost } \\
\text { was } \$ 67\end{array}$ \\
\hline $\begin{array}{l}\text { Whorms, } \\
2021(26)\end{array}$ & $\begin{array}{l}\text { Observational, } \\
\text { Pre-post }\end{array}$ & $\begin{array}{l}\text { Pre- } \\
\text { intervention = } \\
8021 \\
\text { Ride share = } \\
151 \\
\text { Post- } \\
\text { intervention } \\
\text { non-ride share } \\
=7556\end{array}$ & $\begin{array}{l}\text { Patients } \\
\text { scheduled for } \\
\text { MRI at an } \\
\text { urban } \\
\text { academic } \\
\text { health center } \\
\text { Mean age 54- } \\
60 \\
76 \% \text { white }\end{array}$ & $\begin{array}{l}\text { Free ride share } \\
\text { for patients } \\
\text { who } \\
\text { spontaneously } \\
\text { expressed } \\
\text { transportation } \\
\text { difficulty in } \\
\text { pre-visit } \\
\text { reminder } \\
\text { telephone call }\end{array}$ & No & $\begin{array}{l}\text { Same day } \\
\text { cancellations, } \\
\text { timeliness for } \\
\text { appointment, } \\
\text { cost of rides }\end{array}$ & $\begin{array}{l}\text { No statistically } \\
\text { significant } \\
\text { difference in } \\
\text { same day clinic } \\
\text { cancellations } \\
\text { ( } 8.1 \% \text { vs } 8.0 \%) ; 8 \\
\text { minute earlier } \\
\text { check-in time for } \\
\text { ride share } \\
\text { appointment } \\
\text { patients, average } \\
\text { cost of ride = } \\
\$ 17.92\end{array}$ \\
\hline
\end{tabular}

Table 2. Certainty of Evidence Table 


\begin{tabular}{|c|c|c|c|c|c|c|}
\hline Intervention and Outcome & Number of studies & $\begin{array}{l}\text { Study } \\
\text { limitations }\end{array}$ & Consistency & Precision & Other factors & $\begin{array}{l}\text { Overall } \\
\text { Certainty } \\
\text { of } \\
\text { Evidence }\end{array}$ \\
\hline \multicolumn{7}{|c|}{ Certainty of Evidence for Missed Clinic Visits } \\
\hline $\begin{array}{l}\text { Providing free NEMT } \\
\text { transportation reduces missed } \\
\text { clinic visits }\end{array}$ & $\begin{array}{l}7 \text { ( } 3 \text { controlled } \\
\text { trials; } 4 \\
\text { observational } \\
\text { studies) }\end{array}$ & Serious & $\begin{array}{l}\text { No serious } \\
\text { inconsistency }\end{array}$ & $\begin{array}{l}\text { No serious } \\
\text { imprecision }\end{array}$ & $\begin{array}{l}\text { Very strong } \\
\text { mechanism }\end{array}$ & High \\
\hline \multicolumn{7}{|l|}{ Certainty of Evidence for ED Visits } \\
\hline $\begin{array}{l}\text { Providing free transportation } \\
\text { NEMT does not affect ED visit } \\
\text { rate }\end{array}$ & $\begin{array}{l}2 \text { ( } 1 \text { controlled trial; } \\
1 \text { observational } \\
\text { study) }\end{array}$ & Serious & $\begin{array}{l}\text { No serious } \\
\text { inconsistency }\end{array}$ & $\begin{array}{l}\text { Serious } \\
\text { imprecision }\end{array}$ & $\mathrm{N} / \mathrm{A}$ & Low \\
\hline \multicolumn{7}{|l|}{ Certainty of Evidence for Costs } \\
\hline $\begin{array}{l}\text { Providing brokerage service NEMT } \\
\text { transport reduces overall } \\
\text { healthcare costs }\end{array}$ & $\begin{array}{l}1 \text { (observational } \\
\text { study) }\end{array}$ & $\begin{array}{l}\text { Not } \\
\text { serious }\end{array}$ & N/A & $\begin{array}{l}\text { No serious } \\
\text { imprecision }\end{array}$ & $\begin{array}{l}\text { Data restricted to } \\
\text { patients with diabetes } \\
\text { and children with } \\
\text { asthma }\end{array}$ & Low \\
\hline \multicolumn{7}{|c|}{ Certainty of Evidence for Health Outcomes } \\
\hline $\begin{array}{l}\text { Providing free NEMT improves } \\
\text { health outcomes }\end{array}$ & $\begin{array}{l}1 \text { (observational } \\
\text { study) }\end{array}$ & $\begin{array}{l}\text { Not } \\
\text { Serious }\end{array}$ & N/A & $\begin{array}{l}\text { No serious } \\
\text { imprecision }\end{array}$ & $\begin{array}{l}\text { Data restricted to } \\
\text { patients with diabetes } \\
\text { and children with } \\
\text { asthma }\end{array}$ & Low \\
\hline $\begin{array}{l}\text { Providing free rideshare transport } \\
\text { (NMT) improves health outcomes }\end{array}$ & $\begin{array}{l}1 \text { (observational } \\
\text { study) }\end{array}$ & $\begin{array}{l}\text { Very } \\
\text { Serious }\end{array}$ & N/A & $\begin{array}{l}\text { Serious } \\
\text { imprecision }\end{array}$ & $\mathrm{N} / \mathrm{A}$ & $\begin{array}{l}\text { Very } \\
\text { Low }\end{array}$ \\
\hline
\end{tabular}

\section{Figures}




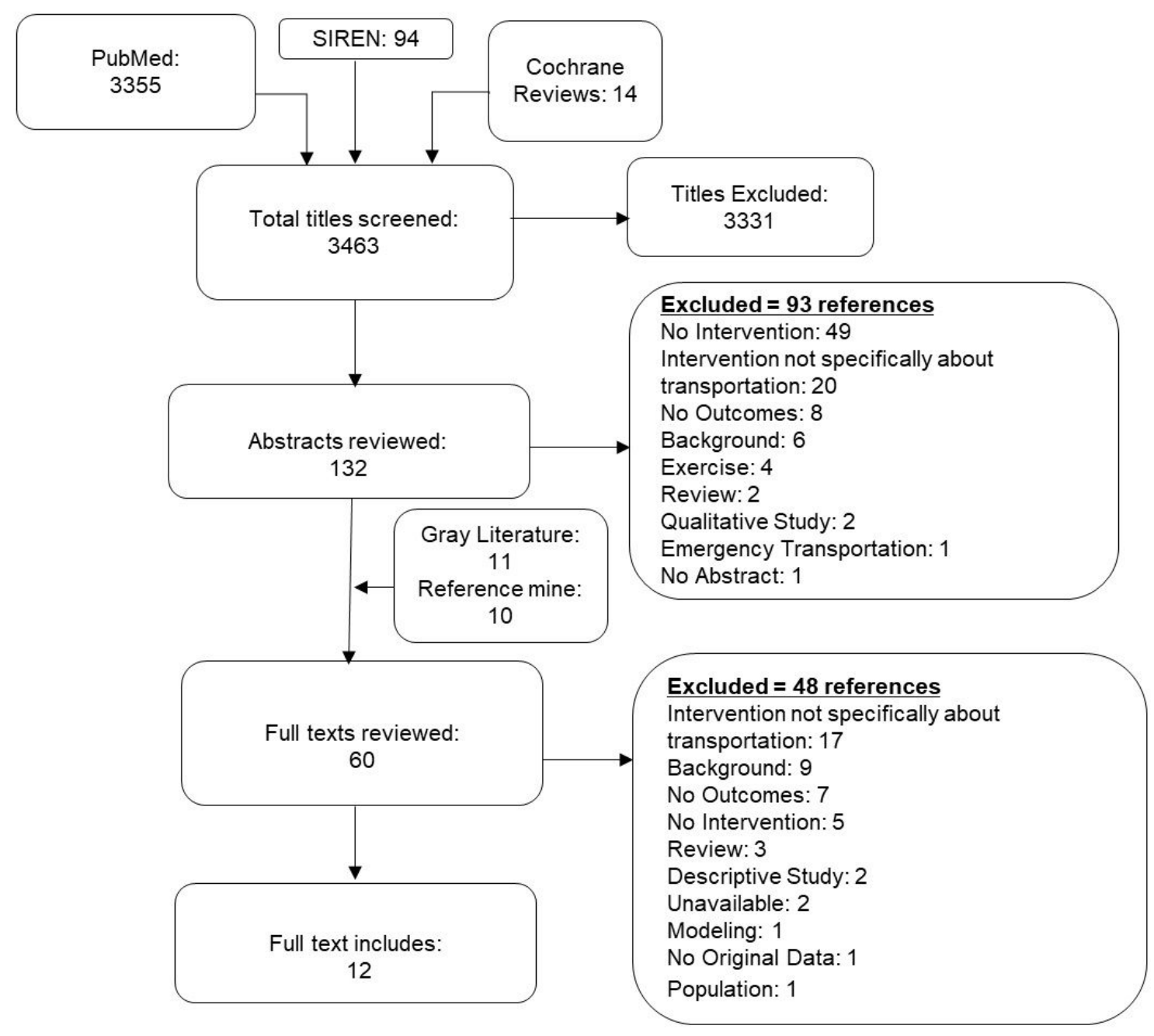

Figure 1

Literature Flow 


\begin{tabular}{l} 
Author, Year (Study Type) \\
\hline Controlled Trials \\
Chalyachat, 2018 (CCT) \\
Meinlikow, 1997 (RCT) \\
Marcus, 1992 (RCT) \\
Pooled result for controlled trials 12=72.2\% \\
Observational Studies \\
Chalyachab, 2018 (pre-post w control) \\
Bryan, 1991 (pre-post wi control) \\
Vals, 2020a (pre-post) \\
Vals, 20200 (pre-post) \\
Pooled result for observational studies $12=76.1 \%$
\end{tabular}

\section{Figure 2}

Effect of Interventions to Reduce Transportation Barriers on Missed Appointments

\section{Supplementary Files}

This is a list of supplementary files associated with this preprint. Click to download.

- TransportationBMCPHAppendices102021.docx 